\title{
Biocompatibility Issues with Modern Implants in Bone - A Review for Clinical Orthopedics
}

\author{
Katja M.R. Nuss and Brigitte von Rechenberg*
}

Musculoskeletal Research Unit, Vetsuisse Faculty, University of Zurich, Switzerland

Vetsuisse Faculty, Equine Hospital, Winterthurerstrasse 250, Ch-8050 Zurich, Switzerland

\begin{abstract}
Skeletal defects may result from traumatic, infectious, congenital or neoplastic processes and are considered to be a challenge for reconstructive surgery. Although the autologous bone graft is still the "gold standard", there is continuing demand for bone substitutes because of associated disadvantages, such as limited supply and potential donor side morbidity [1]. This is not only true for indications in orthopedic and craniomaxillofacial surgeries, but also in repairing endodontic defects and in dental implantology.

Before clinical use all new bone substitute materials have to be validated for their osseoconductive and - depending on the composition of the material also -inductive ability, as well as for their long-term biocompatibility in bone. Serving this purpose various bone healing models to test osteocompatibility and inflammatory potential of a novel material on one hand and, on the other hand, non-healing osseous defects to assess the healing potential of a bone substitute material have been developed. Sometimes the use of more than one implantation site can be helpful to provide a wide range of information about a new material [2].

Important markers for biocompatibility and inflammatory responses are the cell types appearing after the implantation of foreign material. There, especially the role of foreign body giant cells (FBGC) is discussed controversial in the pertinent literature, such that it is not clear whether their presence marks an incompatibility of the biomaterial, or whether it belongs to a normal degradation behavior of modern, resorbable biomaterials.

This publication is highlighting the different views currently existing about the function of FBGC that appear in response to biomaterials at the implantation sites. A short overview of the general classes of biomaterials, where FBGC may appear as cellular response, is added for clarity, but may not be complete.
\end{abstract}

\section{BONE SUBSTITUTES}

\section{Autografts}

Autografts are still the method of choice to substitute damaged or lost bone. The transplanted bone is largely necrotic and acts as a scaffold for the ingrowth of granulation tissue containing osteoprogenitor cells. Under the influence of local factors (cytokines, etc) these osteoprogenitor cells differentiate into osteoblasts that are responsible for new bone formation. At the same time the graft matrix is resorbed through osteoclasts. This process of graft resorption occurring parallel to bone formation was already discovered by Phemister in 1914 [3], who named it "creeping substitution".

\section{Biomaterials as Bone Substitutes}

Bone substitute materials increasingly replace the use of autografts and can be divided into three major classes: polymers, ceramics and natural materials. Nowadays they are used either alone or in combinations called composites [4]. Regardless of their composition, once they are implanted in bone, they also undergo the process of creeping substitution, although the speed and rate of this process may vary according to their composition [5].

*Address correspondence to this author at the The Musculoskeletal Research Unit (MSRU), Equine Department, Vetsuisse Faculty ZH, University of Zürich, Winterthurerstr. 260, 8057 Zürich, Switzerland; Tel: +41-44-635 8410; Fax: +41-44-635 8917; E-mail: bvonrechenberg@vetclinics.uzh.ch

\section{Polymers}

Synthetic polymers represent the largest class of biomaterials useful in applications in both, soft and hard tissue. They can be hydrophobic like silicone rubber (SR), polypropylene (PP), polyethylene (PE) and polymethylmetacrylate (PMMA), or water swelling or even water soluble like polyethylene glycol (PEG). Some of them are degradable, others remain almost unchanged within the body. Polymers are long chained molecules consisting of a large number of small repeating units [6]. They can be amorphous or semicrystalline and their surfaces may be modified chemically and biochemically.

$P M M A$, to cite the most important polymer in current orthopedics, is a permanent bone substitute material which is frequently used to improve the anchorage of fracture fixation devices and joint replacement prostheses. It is also used in vertebroplasty in severe cases of impact fractures of the vertebral body due to osteoporosis or neoplasm [7, 8]. Although this material has proven its usefulness in these applications, on the other hand it poorly osseointegrates even possibly disturbing bone healing and remodeling through its genuine inert properties. Additionally tissue necrosis may be caused through heat production up to $80^{\circ} \mathrm{C}$ while curing and by creating monomer toxicity $[9,10]$. In combination with primary (micro-)mechanical instability these properties may lead to the formation of an interface membrane and subsequent 
aseptic loosening [11-13]. Despite all those concerns, PMMA is still the most frequently used polymer bone cement in Europe [14].

Hydrogels are novel polymers that gained more popularity in recent years. As an example for degradable water containing substances they can be injectible and of different water contents. They can consist of Poly-(ethylene glycol) [15], or gelatine [16-18].

They are used experimentally and clinically as biomaterials for the controlled release of bone regeneration activity enhancing substances like Transforming Growth factor (TGF)-beta 1, Insulin-like growth factor (IGF)-1 and bone morphogenetic protein-2 [19-22] Furthermore, hydrogels can also be used as scaffolds and carriers for osteoprogenitor [23] and other cells like chondrocytes, fibroblasts and mesenchymal stromal cells.

\section{Ceramics}

Ceramics are a large family of inorganic/non-metallic compositions with a wide range of characteristics depending on the processing method used. They can be dense, porous or non-porous and resorbable like tricalcium-phosphate [24], porous, inert and lead to bone ingrowth like hydroxyapatitecoated porous metals, or dense, non-porous, surface active materials, that attach to the bone by chemical bonding like hydroxyapatite. In this chapter only the most frequently used ceramics are cited as examples.

Calcium phosphates represent a group of materials, where their properties depend on the calcium-phosphate ratio and modification of crystallinity and porosity. They are biocompatible, osseoconductive and degradable $[25,26]$ by extracellular dissolution of the calcium orthophosphate material [27] and by a cell mediated resorption [28] similar to the bone remodelling or bone substitution observed with autografts [3]. Their degradation time may last up to years, depending on the type of material.

Calcium phosphate ceramic blocks are brittle, highly susceptible to fatigue fractures and therefore of limited use in complex weight bearing locations [29]. Furthermore, their preset structure may render it difficult to adapt them to local defect sites. If used in blocks, their shape may not be corresponding to the original bone defect and if used as granules it may be impossible to keep them at the implantation site.

Calcium phosphate cements can overcome this problems partially as they can be administered in paste form and injected into bone defects, which makes adaptation to local requirements very easy. In addition, they can be administered through the tissues without the need of open approaches to the injection sites. They harden without elevation of temperature. Depending on the individual composition and $\mathrm{pH}$ the cement setting results in brushite-cement $(\mathrm{pH} \leq 4,2)$ or hydroxyapatite $(\mathrm{pH}>4,2)[30]$. There are more than 100 different formulations of calcium orthophosphate cements available, which can be divided into four classes: dicalciumphosphate dihydrate, calcium and magnesium phosphates, octocalciumphosphate and non-stoichiometric apatite cements [31].

The use of $\beta$-tricalcium phosphate ( $\beta$-TCP) is limited by its unpredictable rate of resorption and also its biocompatibility is discussed controversary. Levin [32] reported the presence of giant cells when tricalcium phosphate was implanted, whereas Jarcho [33] to the contrary stated, that there was no foreign body cell response. On the other hand, there is consense about ist osteoconductive properties [28, 33, 34].

Dicalciumphosphate is one of the most soluble of calciumphosphate phases and can be used when quick degradation is required [35]. All cements of this group are the product of an acid-base reaction and it shows good osteoconductive properties. Despite the setting $\mathrm{pH}$ being quite low, tissue necrosis as a response has not been detected [31].

Hydroxyapatite is used as implant coating [36], granules $[37,38]$ and in block structure [39]. It has a similar chemical composition as the mineral fraction of bone and attaches close to hard tissues. It is able to fill gaps between bone and implant up to $2 \mathrm{~mm}$ and stimulates bone ingrowth even in osteoporotic bone [40]. In contrast to $\beta-\mathrm{TCP}$, hydroxyapatite bone substitutes are considered non-resorbable. However, this is only partially true since also hydroxyapatite substitutes degrade in vivo, albeit much slower compared to $\beta$-TCP or brushite compositions [30, 41, 42].

Hydroxyapatite-coated implants integrate well with the bone healing process $[39,43]$. This characteristic, called "osteophilic" [36], provides a good substrate for osteoblasts. The use of hydroxyapatite as a coating of implants, therefore, is quite common. However, some authors found out, that it can lead to osteolysis when it is exposed to bone marrow and soft tissues [44]. There, the hydroxyapatite wear debris is thought as the main cause for implant failure [45] as its phagocytosis stimulates the release of cytokines. Subsequently these products are held responsible for (granulomatous) inflammation, disturbance in bone remodelling and local osteolysis.

Natural materials: Natural polymers such as silk, cellulose, collagen, proteoglycans, glycosaminoglycans and elastin are often quite similar to natural occurring substances which makes it easy for the body to recognize and degrade these materials by physiological mechanisms [46]. On the other hand they are immunogenic and the technological manipulation to avoid tissue reactions are elaborate and sometimes cost intensive.

\section{HOST RESPONSE}

Implanted biomaterials are always recognized as foreign by the body, independent on how elaborate the biocompatibility was previously tested. All medical devices and prostheses implanted in connective tissue immediately induce an initial host response to act against the foreign body. The type of implant-tissue response can be graded according to Hench [24]: if the material is i) toxic, the surrounding tissue dies, ii) nontoxic and biologically inactive (nearly inert), a fibrous tissue of variable thickness forms, iii) non-toxic and biologically active (bioactive), an interfacial bond forms, and iv) non-toxic and dissolves, the surrounding tissue replaces it.

This acute inflammatory reaction resembles in large the normal wound and fracture healing process [47] and consists of cellular and molecular components. The magnitude [48] and duration of the inflammatory process has a determining influence on the stability and compatibility of the implanted medical devices. 
The foreign body reaction starts within seconds or minutes after tissue contact [49] with a conditioning film of glycoproteinaceous materials called "opsonins" on the surface of the implanted device [50]. Albumin, fibrinogen, immunglobulin $\mathrm{G}$ and complement components are the most abundant proteins on the surface of polymers [51]. While the deposition of fibrinogen and mainly immunogloblins is considered as an active process and tissue response to the foreign material, the deposition of albumin probably can be ruled out as being part of this reaction, because it seems to more passivate the surface of implants [49]. Nevertheless, some authors found out, that the entire protein layer seems not to be critical for the immune response as either IgG deficient or complement depleted mice showed a regular reaction against foreign bodies [52].

This layer, recognized by the integrin receptors present on neutrophils and macrophages, plays an important role since it converts the implant into a biologically recognizable material [53]. It initializes monocyte attraction and migration through the endothelium through mast cell activation and associated histamin release as the next step of host response [54].

This is followed by a fibroblast invasion and synthesis of extracellular matrix through these activated fibroblasts [55]. It ends up in an inner layer of macrophages and/or foreign body cells with an outside secondary zone of layered fibroblasts and connective tissue [56] surrounding the implanted material. This reaction is unique and does not seem to depend on the type of implant [57]. The magnitude of the pe- riprosthetic or peri-material reaction and the thickness of the inflammatory layer is said to be an index for the biocompatibility of the implant [58] as it depends on the chemical and topographical nature of the surface of the device.

Most of the routinely applied biomaterials have excellent characteristics related to biocompatibility in bulk form. Sometimes the foreign body reaction is clinically first seen when the implant is disintegrated [59-61]. The failure of implants seems to be connected with the interfacial accumulation of wear particles in case of metals and degradation products in combination with biodegradable materials $[27$, 62-64]. The discussion about biocompatibility is controversial $[58,65,66]$, but there is a certain agreement, that the extent and intensity of tissue reaction defines the biofunctionality of an implant, rather than the response by itself [67]. In other words: not the lack of host reaction, but the appropriateness of the answer is important.

The question addressed in this article was, how this appropriateness could be defined through the appearance of different cells in the implantation site.

\section{CELLULAR REACTION AFTER BIOMATERIAL IMPLANTATION}

In bone healing processes connected with the implantation of foreign materials a specialized group of cell types with different characteristic abilities can be found (Fig. 1).

The first cells attaching to the implanted material are the fibroblasts. They produce immature collagen that is laid down onto the surface of the implant $[51,55,56,68,69]$.

IMPLANTATION OF BIOMATERIAL

INFLAMMATORY CELL INFILTRATION

(MONOCYTES, LYMPHOCYTES)

EXUDATE/ TISSUE

BIOMATERIAL

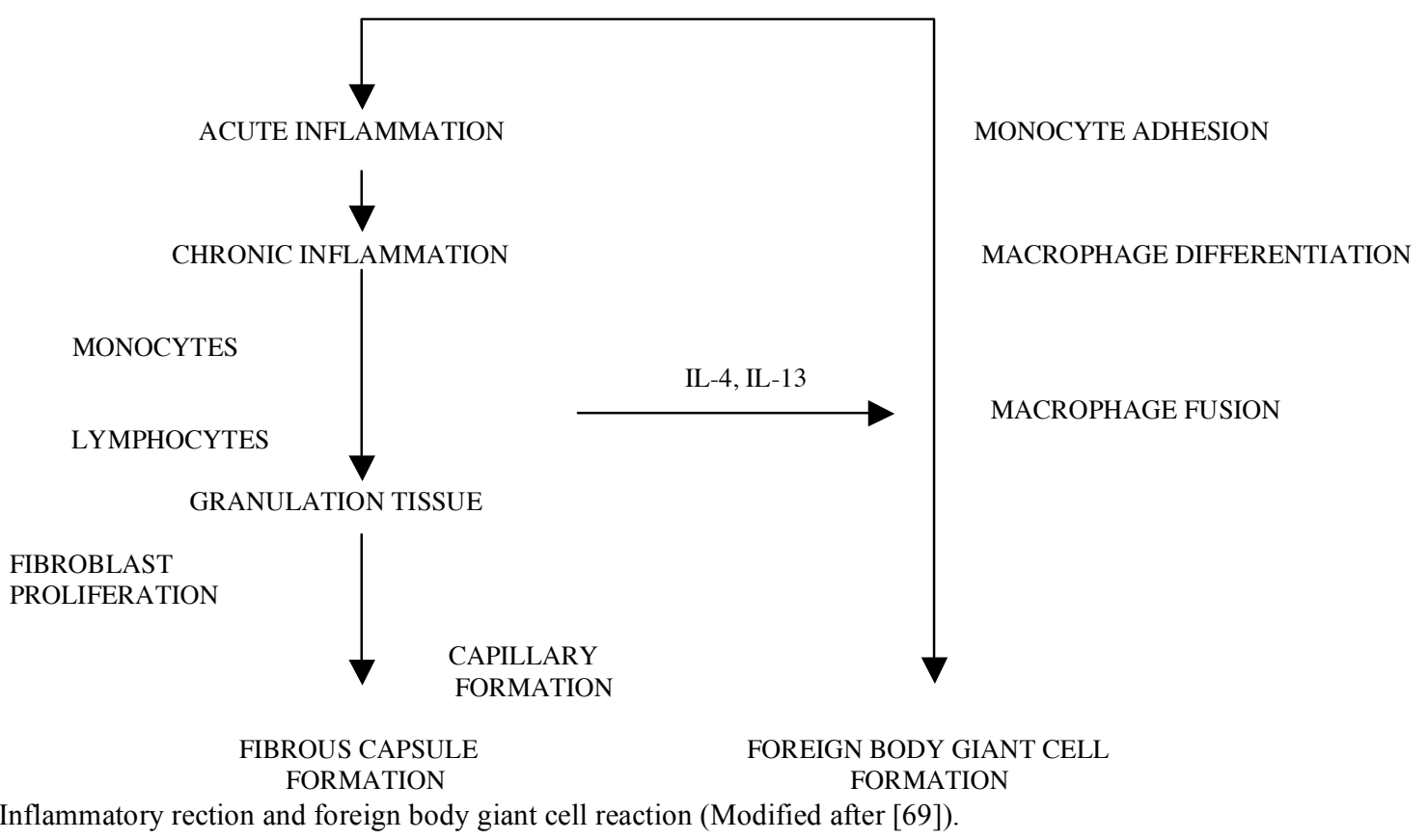

Fig. (1). Inflammatory rection and foreign body giant cell reaction (Modified after [69]). 
These cells are recruited from the mesenchymal tissue surrounding the implanted material or fracture site upon release of signal transduction molecules of the resident bone and hematoma cells. These signals are also responsible for initiating the cascade of bone formation and resorption pertinent to fracture and/or defect healing, resp. bone remodeling [69].

Among the bone forming cell types, osteoprogenitor cells are detected at the inner layer of the periosteum. These cells can differentiate into osteoblasts under the influence of Bone morphogenetic protein (BMP)-2, which apart from osteogenesis also stimulates angiogenesis in bone healing. Under the condition of low oxygen tension the progenitor cells may also differentiate into chondrogenic cells. Osteoblasts, derived from osteoprogenitor cells synthesize the organic components of the bone, such as collagen, proteoglycan and glycoproteins (Fig. 2). After their differentiation they express bone specific alkaline phosphatase (ALP), which therefore, is a late marker of bone formation. Osteocytes derived from osteoblasts are mature bone cells, that became trapped in their lacunae. Osteocytes keep in contact to each other by cytoplasmatic processes, through which ions and small molecules can move between the cells [70].

(a)

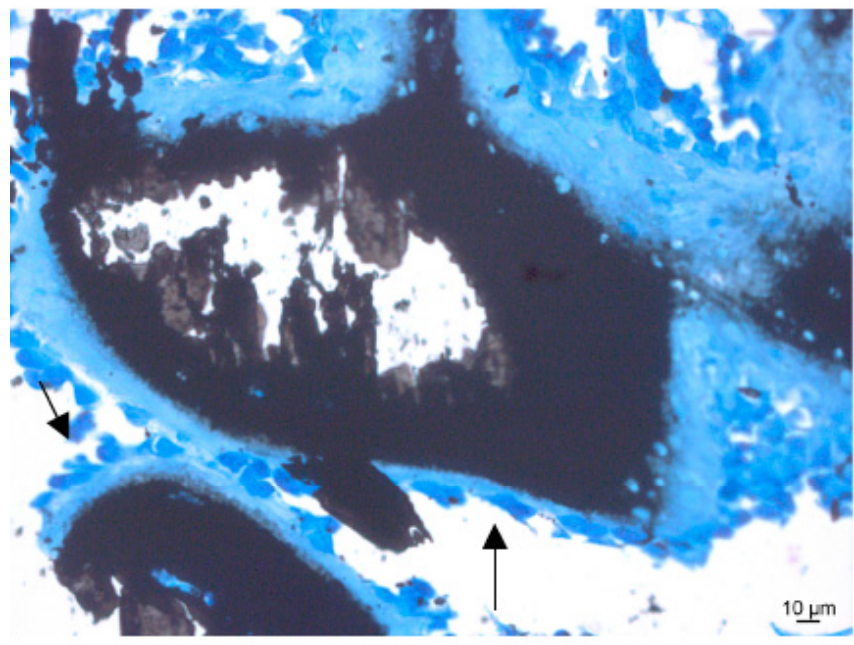

(b)

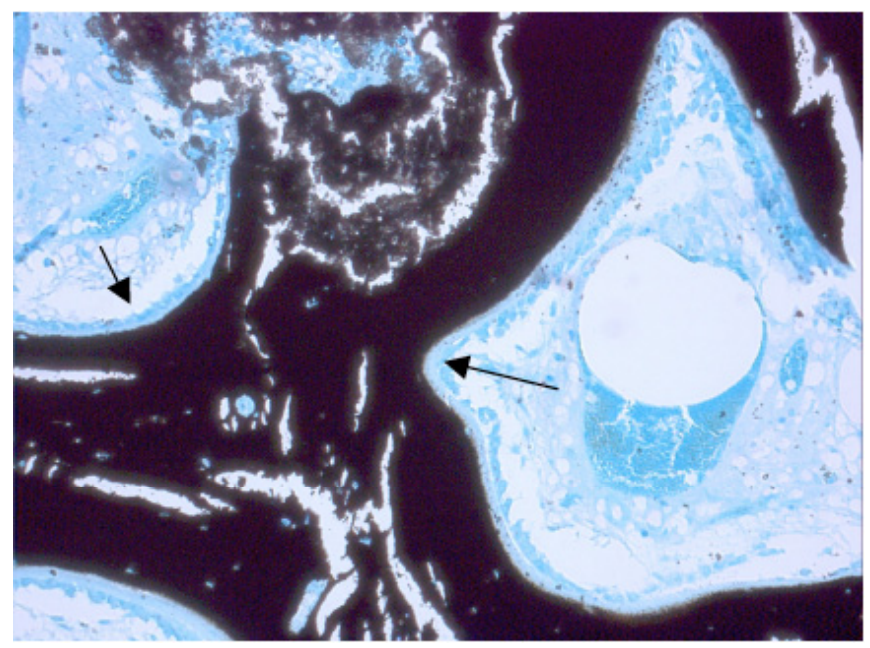

Fig. (2a,b). Seams of osteoblasts (arrows) close to a natural bone substitute (Kossa 20x, 10x).
Cells responsible for bone (or material) resorption are connected to the osteoclast lineage. The precursor cells of osteoclasts come from the bone marrow and are called granulocyte-macrophage progenitor cells [71]. They are thought to derive from the blood macrophages. Upon stimulation by local signalling molecules, mediators and cytokines (such as receptor activator of nuclear factor-B ligand (RANKL), prostaglandin E2, interleukin (IL)-1 and 6) these originally mononuclear cells fuse to become multinucleated cells generally found on mineralized surfaces in bone (Fig. 3) Osteoclasts are responsible for resorbing bone, especially the woven bone which first appears after a bone wound has

(a)

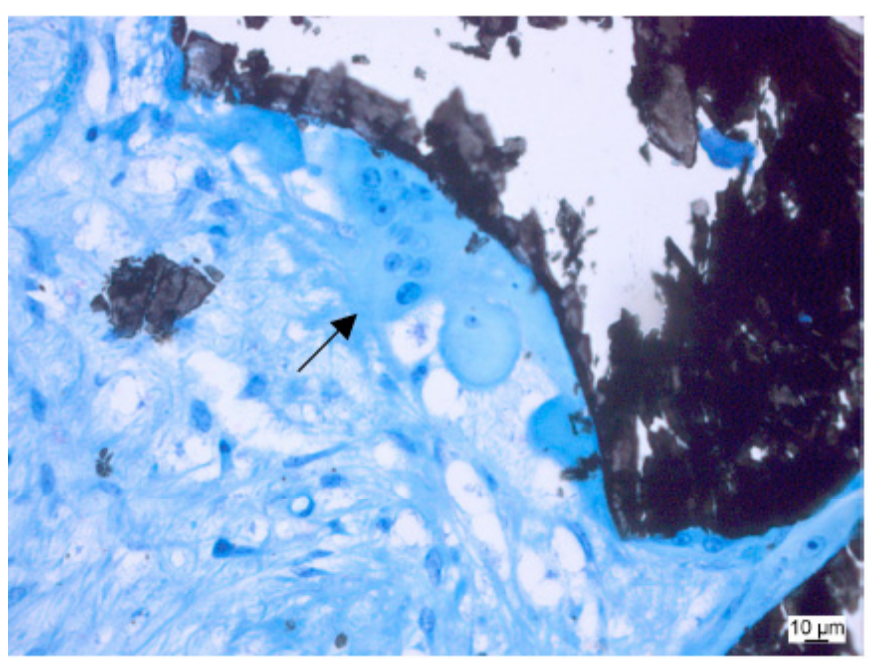

(b)

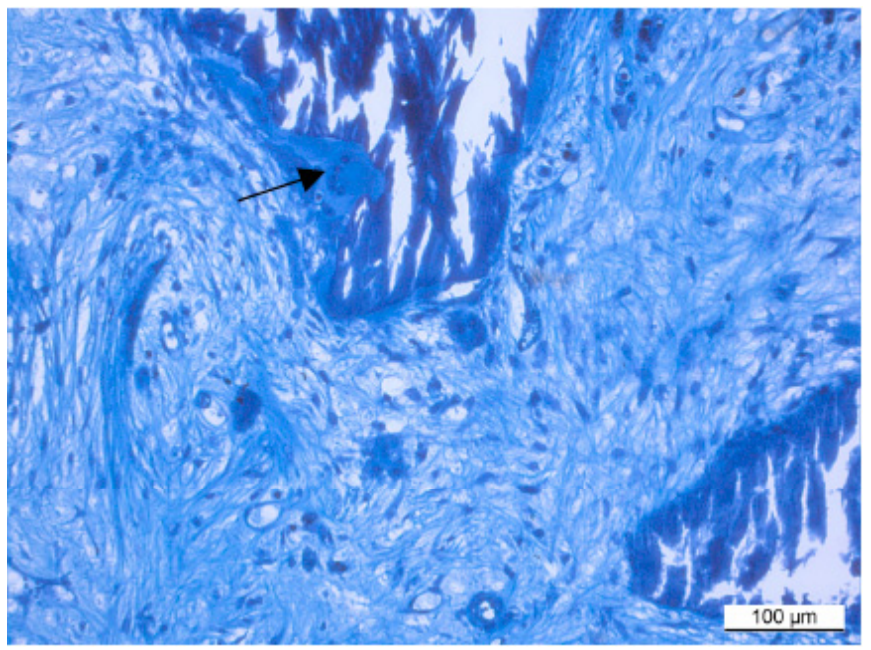

Fig. (3a,b). Osteoclasts degrading a natural bone substitute material (arrows). (Kossa 20x, Toluidinblue 10x).

been produced, such that this immature substitute can be replaced by lamellar bone. It is not always possible to distinguish osteoclasts from foreign body cells (FBGC) with certainty. Osteoclasts resemble foreign body giant cells morphologically but have calcitonin receptors on their surface. To distinguish osteoclasts from FBGCs immunostaining of osteocalcin receptors would, therefore, be the modern method of choice. Formerly, special stainings for the tartrateresistant acid phosphatase (TRAP): TRAP [72] were rou- 
tinely performed for this task. Some authors found out, that the TRAP-coloration was not entirely specific for osteoclasts [73]. However, technical problems with immunostainings in bone especially in larger animal species and in combination with biomaterials, where bone samples have to be embedded in plastic sections, make it impossible to successfully use osteocalcin antibodies for osteoclast identification.

Osteoclasts can carry out the highly specialized function of lacunar bone resorption, but it is generally believed that they do not phagocytose particles of biomaterials at the bone-implant interface [74]. However other investigations show, that they are capable of phagocytosing both polymeric and metallic biomaterial particles. This lead to the conclusion, that not all multinucleated cells, that contain wear particles and can be found next to osteolysis are FBGC [75].

In the line of defense, lymphocytes and plasma cells produce antibodies to protect the body against foreign antigens, they are seen in greater numbers in areas of more chronic inflammation and where foreign substances have entered the tissue [56, 65, 68, 69, 76-80] (Fig. 1). Neutrophils participate in the foreign body reaction by releasing lytic enzymes [81]. Usually neutrophil polymorphs are found in the immediate period after lesions were created for wound debridement, but mark the presence of (sub-)clinical bacterial infection if found later in the wound healing period.

In addition, two other cell types are also especially interesting considering cellular defense mechanism to foreign material: macrophages and foreign body giant cells (FBGC). There is no general agreement in the literature about their character of being inflammatory and thus, negative for the process, or just belonging to a normal response in degrading materials.

Macrophages derive from the mononuclear phagocyte system. All members of that system arise from a common stem cell in the bone marrow, possess lysosomes and are capable of phagozytosis. In the first few days after a fracture has occurred or a bone defect has been produced, granulation tissue grows in between the fracture ends or edges respectively. As mentioned above, neutrophil polymorphs are the type of cells which can be found most frequently in this period. The macrophage derived interleukin-1 may cause neutrophil infiltration, induce angiogenesis and antibody production and lymphokine synthesis [82]. Later more chronic inflammatory cells like macrophages are found, which remove red cells, necrotic fat and tissue debris [76]. These are transformed monocytes which arrive at the implantation site via a complex pathway of chemotactic and chemokinetic agents like mast cells/histamine [54], and Tumor Necrosis Factor (TNF) -alpha [83] release, complement factors, lymphokines, chemokines, platelet factors, leukotrienes and eventually bacterial fragments [84]. They adhere to the biomaterials via several adhesion ligand-receptor superfamilies [80], such as with an integrin binding [68]. Certain biomaterial-adsorbed proteins promote monocyte adhesion. The most active in this regard are fibrinogen, fibronectin and immunglobulin G [85-87].

After adhesion they transform into macrophages which are characterized by cell enlargement and an increased secretion of inflammatory mediators (cytokines and chemokines), an increased expression of membrane proteins (e.g. in- tegrins) $[88,89]$ and the expression of angiogenic and other growth factors [80]. The released factors attract different cell types like additional macrophages, neutrophils, fibroblasts and other cells [89-92].

Macrophages are cells that secrete factors to promote physiological wound healing. Some of the macrophages may also function as accessory antigen-presenting cells [93]. On the other hand, they can be the central cellular mediators of the chronic inflammatory response to foreign materials [56] by secreting monocyte chemoattractant protein-1 (MCP-1) contributing to the development of the foreign body reaction [94], disturbing wound healing and ultimately contributing to implant failure.

Macrophages phagocytose damaged cells, cellular debris and foreign substances and digest the ingested material by hydrolytic enzymes in their lysosomes. While this mechanism functions for several biomaterials in the same way, their enzymatic apparatus is not able to degrade synthetic polymers [95]. Some authors consider the presence of macrophages around or near biomaterials to be part of a chronic inflammatory reaction, whereas others relate to them as part of the normal degradation behaviour, at least in case of degradable materials in bone [27, 62, 96, 97] (Fig. 4).

Macrophages also modulate the tissue reaction through production of interleukins, growth factors and other bioactive agents and most importantly they are the precursors of osteoclasts and foreign body giant cells. The role of RANKL and what triggers the fusion and further differentiation into osteoclasts or foreign body giant cells is not entirely clear [96, 97].

Mechanical wear of implants (the smaller the more) [45] activate macrophages to phagocytosis which in turn induces secretion of TNF- $\alpha$, IL-1 1 , IL- 6 and prostaglandin (PGE) $)_{2}$ $[45,98]$ that stimulates differentiation of osteoclast precursors into mature osteoclasts [99]. This effect leads to bone resorption and in excess can induce implant failure [100]. While in debate whether osteoclasts contain foreign material in their cytoplasm, it also has been shown, that macrophages, which have phagocytosed particles, are capable of osteoclast differentiation [101].

Interaction of macrophages and lymphocytes are complementary. It is likely that the adhesion of macrophages to a surface also is the initial signal to activate the lymphocytes which in turn release molecules that furthermore influence macrophage activity [77] and fusion [81, 102-104]. Therefore, the presence and activity of lymphocytes may be a determining factor in excessive resorption behaviour or ultimate biocompatibility questions.

Macrophages also modulate in the process of tissue repair. Since they derive from the vascular system, a good vascularity, therefore, is one of the important factors [105]. Animals depleted of macrophages or having received antimacrophage monoclonal antibodies show deficient wound healing [106].

Foreign body giant cells are present in cases of bone defect healing with or without autologous bone grafts and play a significant role if biomaterials are applied. In case of biomaterials and bone controversy exists in whether they are part of normal bone healing or material degradation, or 
whether they play a significant role in issues of bioincompatibility.

(a)

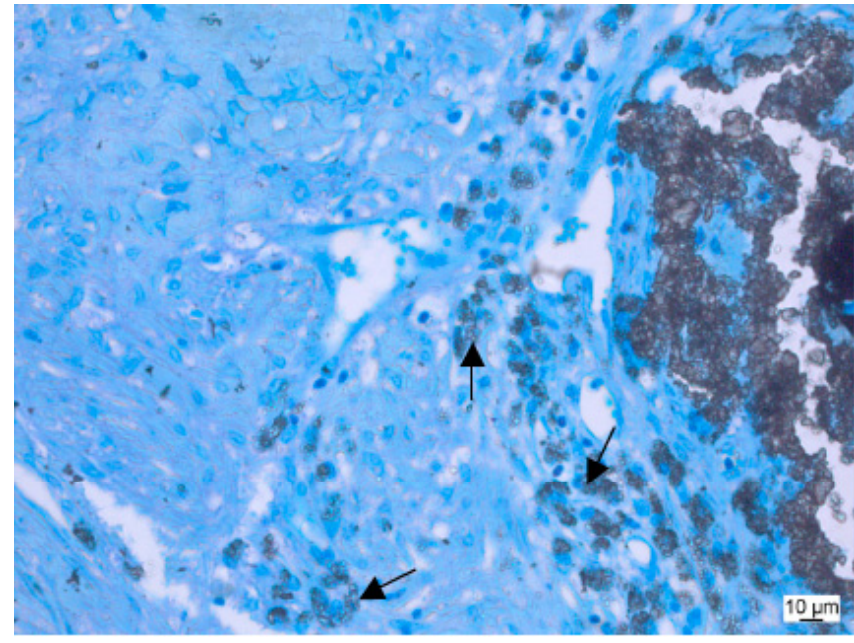

(b)

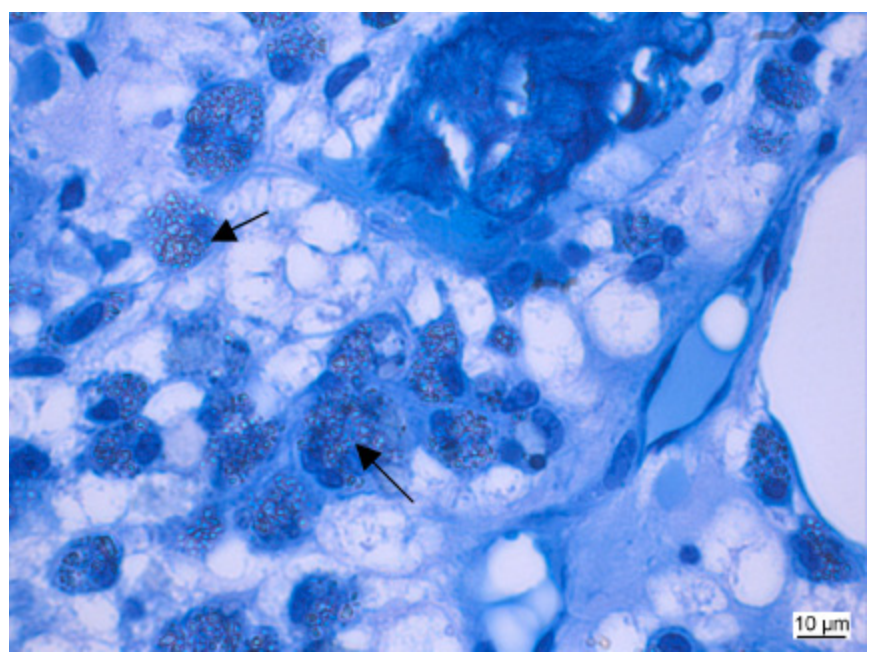

Fig. (4). Biocompatibility study of a biomaterial as bone substitute in sheep bone. Macrophages (arrows) with ingested foreign material. (a: Kossa 20x, b: Kossa 40x).

Under chronic inflammatory conditions and if the matter to be disposed is very large (bigger than the diameter of a macrophage [27], than $80 \mu \mathrm{m}$ [95], $5 \mu \mathrm{m}$ [44], $12 \mu \mathrm{m}$ [35]), or indigestible for osteoclasts [107, 108], several macrophages fuse to form a foreign body giant cell [109]. Anderson [69], in contrary, has the opinion that ,the presence of mononuclear cells, including lymphocytes and plasma cells, is considered chronic inflammation, whereas the foreign body reaction with the development of granulation tissue is considered the normal wound healing response to implanted biomaterials". His view in regard to foreign bodies is similar to Lassus et al. who considers macrophages to be part of the normal degradation process $[96,97]$.

The mechanism of cellular fusion of macrophages to FBGC is similar to phagocytosis and is mediated by several mediators $[110,111]$, but little is known regarding the biological responses which are considered to influence the transition to FBGC development [69].
It can lead to very large cells (up to $1 \mathrm{~mm}^{2}$ ) with hundreds of nuclei $[112,113]$. FBGCs are also generally observed in granulomas induced by bacterial pathogens, such as in tuberculosis or trichinellosis, which is probably the main reason for the negative association with their presence in tissue.

Cytokines like interleukin-4 and 13 are known as potent inductors of macrophage fusion into FBGC [103, 114, 115]. They also play a central role in cellular reactions which cause bone lysis around implants [116] as they modulate the balance between osteoblasts and osteoclasts [117]. The injection of anti-interleukin-4-antibody significantly decreased FBGC density on polyetherurethane ureas in vivo [102].

Foreign body giant cells act to concentrate phagocytic and degradative activities at the host-implant interface. They ingest and dissolute implanted material intracellularly or by the release of degradative agents like lysosomal enzymes and reactive oxygen intermediates (ROIs) at the ventral cell surface [118] in response to certain stimuli, whereby their phagocytic capacity can be as effective as macrophages [119]. They also can directly contribute to osteolysis by differentiation into TRAP-positive osteoclast-like cells [120122].

FBGC rapidly differentiate after the implantation and progressively decrease with time [123]. Their size depends on the intensity of the inflammatory response [124]. They resemble osteoclasts morphologically, such that both are multinucleated, are found near implant/bone contact and have a cytoplasm with many vacuoles (Fig. 5). FBGCs contain great numbers of mitochondria of various size and oval or round nuclei. Rough endoplasmatic reticulum is found throughout the cytoplasm [125]. The osteoclast on the other hand is defined as possessing a resorbing apparatus consisting of ruffled border and clear zone, expression of the tartrat-resistant acid phosphatase and the expression of calcitonin-receptors [125]. However, it has to be kept in mind that other authors question whether the TRAP-epitopes as well as other markers (such as calcitonin receptors) are specific for osteoclasts [73].

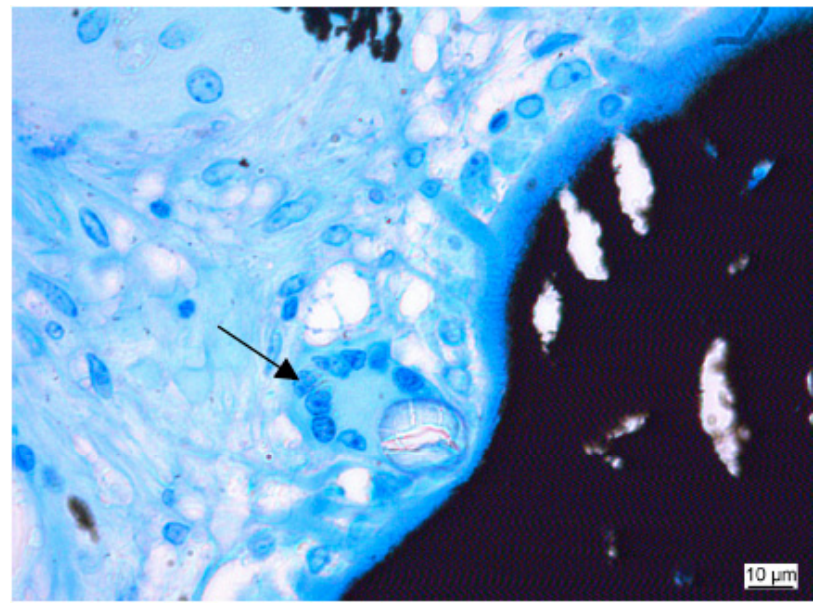

Fig. (5). Foreign body giant cell (arrow) close to implanted material. (Kossa 40x).

One of the most important aspects in the evaluation of biomaterials is the degradation resistance, with the exception of the class of biodegradable polymers, that rely on enzymes, 
acid or ROIs for degradation of the polymer matrix [126]. The discussion about the role of FBGCs is controversary with the main question being whether the presence of FBGCs near an implant is just a sign of biodegradability [126], therefore a part of normal bone healing and resorption after the implantation of a bone substitute, or a sign of insufficient biocompatibility, inflammation and implant failure? Both sides have valuable arguments ready which are outlined below.

The arguments in favour of the FBGC are that i) these cells are part of the normal wound healing response to implanted inert or biodegradable biomaterials [56, 127], ii) their presence does not impair bone formation [31], iii) the presence of FBGCs indicates a low degradability of the implanted substance $[125,128,129]$, iv) FBGC in the absence of other inflammatory cells show a good biocompatibility [107], and most importantly v) macrophages and FBGCs mediate material resorption and fragmentation of biodegradable implants [125, 129-131]. The latter is supported through the fact that resorbed material could be seen in intracytoplasmatic vacuoles by transmission electron microscopy [132]. Furthermore, the implantation bed of resorbable polyL-lactide (PLLA) plates and screws showed a "foreign body reaction without signs of inflammation": only a few polymorph nuclear leucocytes were present and the remnants of the plates and screws were surrounded by connective tissue with macrophages, foreign body giant cells and fibrocytes. The foreign body reaction was thought to be evoked by very small particles $(22 \mu \mathrm{m})$ of disintegrated PLLA plates and screws [61] and the amount of the degraded material seems to influence the intensity of the foreign body reaction [133]. This view, that FBGC are responsible for the degradation of biomaterials, is further supported by the analyses of retrieved implants showing material surface cracks directly under adherent FBGC [113]. If macrophages and foreign body cells are part of the normal wound healing process, the foreign body cells may persist for the lifetime of the implant, it is not known if activated or quiescent [69]. Biocompatibility may be in jeopardy, if the presence of a large mass of disintegrated material seems to "exceed the local tissue tolerance" [61]. Here, the question arises where the line has to be drawn for local tissue tolerance?

The arguments pointing towards FBGC being a a bad sign for tissue tolerance are that i) the fusion of specialized macrophages is induced by poorly tolerated foreign bodies $[78,112,134]$, ii) avoiding monocyte or macrophage adhesion and FBGC formation, inflammatory degradation could be minimized [135], iii) the presence of macrophages and FBGC is associated with structural and functional failure of the implant [136], and iv) FBGC seem to concentrate the phagocytic and degradative activities at the tissue-material interface and therefore are responsible for the damage and failure of the implant. For the latter the authors tested coating the surface of an implant with a material that promotes programmed cell death to inhibit the adhesion and fusion of macrophages into FBGCs [137].

Fibrous capsule formation close or around an implanted biomaterial is frequently seen. The reasoning behind it is that if the implanted biomaterial cannot be ingested by macrophages and FBGCs ("frustrated phagocytosis") the next best protection for the host seems to be the isolation of the for- eign object. This can be achieved best by a layer of FBGC in a fibrous, quite avascular capsule limiting further interaction between host and implanted device. The capsule type depends on the secreted cytokines $[95,138]$, the extent of injury or defect created and the amount of provisional matrix [69].

On one hand this fibrous capsule may indeed downsize the inflammatory reaction, but on the other hand in osseointegration processes can lead to device failure and restricted nutrient supply. Poor tissue device contact can lead to infection. A fibrous layer (so called interface membrane) between methylmethacrylate and an implant has shown to be morphologically synovial-like [55]. In well fixated or coated [139] implants the interfacial membrane is thin with only some macrophagic aggregates. The quantity and quality of the fibrous scar tissue depends on the implantation technique and the prosthetic material used [11-13,55].

\section{INFLUENCES ON BIOCOMPATIBILITY AND FOR- EIGN BODY RESPONSE}

The type of biocompatibility and foreign body response depends on the chemical composition/surface character, morphology, localization of the implant the surgical technique and mechanical loading [140,141]. Besides that, degradability, hormonal and humoral influences play an important role.

\section{Implant}

Surface morphology: The implant surface-tissue interface is the most important relationship for biocompatibility in vivo especially in metallic implants but also in other biomaterials [81] as the surface character influences the nature and magnitude of the foreign body reaction [142]. The biocompatibility of an implant and the irritation of the surrounding tissue depends on different parameters like hydrophobicity/hydrophilicity, wettability, surface charge, polarity, surface energetics, mobility of the surface molecules and smoothness. Thereby it seems to depend more on physical attributes than on the implant's chemical composition [65].

The hydrophilic surface of hydrogels for example has a small amount of interfacial free energy to react with body fluids and this results in a low tendency for proteins and cells to adhere and grow onto these surfaces [143, 144].

In the contrary Eriksson et al. [145] compared the healing response between hydrophilic and hydrophobic implant surfaces and found out, that the difference in the adherence of viable cells can be seen only initially. A certain roughness of an implant prevents excessive tissue motion and therefore results in a relatively thin soft tissue layer in comparison to the polished surface of the common stainless steel implants [146]. On the other hand the resulting surface enlargement can increase the risk for corrosion.

Cells do not adhere directly to the surface of synthetic implanted materials, but to extracellular matrix proteins. Implants coated with phosphorylcholine have been shown to reduce this protein adsorption and this resulted in a lower inflammatory response and a lower fibrous capsule thickness [139].

Some authors refer to implant failure as a ,small particle disease" especially with metallic devices, because the inter- 
facial membrane is full of implant debris [63]. The physical characteristics of those particles play an important role in the resulting inflammatory reaction [45]. To avoid excessive particle formation mechanical biostability is especially important in implants that are planned to remain in the body for a long time [11-13].

Materials composed of elements near to calcium and carbon in the periodic system are more biocompatible over time than others, because the body is composed mostly of those elements and water [81, 147]. If implants release drugs, the original situation may change again and the biocompatibility of the devices is affected by the bioactive compounds they deliver to the surrounding tissue [148].

Hochuli-Vieira et al. [127] compared the body's reaction on titanium plate and PLLA/polyglycolic-acid (PGA) implant fixation after mandibular osteotomy in rabbits. The PLLA/PGA plates and screws were partially degraded after 30-60 days. The implants were wrapped in connective tissue with some macrophages and FBGCs. No specific inflammatory reaction was seen, but "some macrophages were in contact with the screws" or "some scarce giant cells and macrophage cells around them" after 30 days of implantation.

An essential prerequisite for osteoconduction is the direct, stable and extensive enough contact between host bone and the implanted material. One way to optimize the biocompatibility of an implant could be to coat the surface with a biocompatible film [149]. However, the best biocompatibility may be achieved when tissue can grow into the pores of the implanted material. As pores smaller than $50 \mu \mathrm{m}$ exclude macrophages to clear bacteria away, pore size, therefore, should be about $60 \mu \mathrm{m}$ to avoid bacterial infection [30, $62]$.

On the other hand high-surface-to-volume-implants as porous devices are said to have higher ratios of macrophages and FBGCs in the implant site [69]. Bone ingrowth seems to increase with the size of the pores [150], at least initially but not in the long run. Pore dimensions of at least $10 \mu \mathrm{m}$ seems to be necessary for connective tissue ingrowth [151]. A minimal pore size of more than $100 \mu \mathrm{m}$ [24], even of 200$400 \mu \mathrm{m}$ has been recommended [152], the latter being close to the average size $(223 \mu \mathrm{m})$ of the human osteon.

Degradability: Most synthetic polymers are degraded through hydrolysis, whereas most biopolymers such as collagen are degraded through enzymatic attack. An optimal degradable scaffold material should be degraded and resorbed at the same rate as the tissue grows into the implant and replaces it with natural bone [153] as nondegraded polymers are preventing complete ossification. Polylactides, for example, degrade slowly through hydrolyzation, and some residues can be found in the region of implantation up to 2 years [128].

Bone healing studies have shown, that there is a "bone signal window" about 7 to 12 weeks after injury. After that time the natural bone healing signal disappears and a fibrous tissue scar will be the result. Therefore, the authors conclude that an implant should degrade up to 12 weeks, at least in bone [154].

After the implantation of $\mathrm{Ca} / \mathrm{P}$-apatite-coated polylactone sponges and non-coated sponges as a control FBGC were observed in close contact to all implants. Their number seems to correlate with the amount of non-degraded and not on the composition of the material [128]. As mentioned above, it may be difficult to draw the line which rate of degradability and subsequent FBGC formation is still tolerable as part of normal wound healing processes and where bioincompatibility issues start.

Any material implanted elicits a defensive process, but modern biomaterials can be well accepted by the tissue in which they are implanted. Their particular breakdown products on the other hand can induce a severe inflammatory reaction [63]. The cellular activity while PLLA plates are resorbed showed a dense layer of macrophages in the first few weeks and in the end stage of the resorption process after 104 to 143 weeks [155]. The changes in biomechanical properties and morphology due to the degradation may intensify the foreign body reaction [156]. It has been stated by several authors that the accumulation of macrophages is a general biomaterial phenomenon related to degradable biomaterials [157-160].

Localisation: Biocompatibility depends on the surface structure of the medical device and, of course, also on the tissue, in which it is implanted $[64,161]$. Medical devices implanted in different tissue types provoke a different reaction. Here, the statement of Williams should be remembered, that "the unique cicumstances pertaining to individual cases have to be considered when defining biocompatibility" [162].

\section{Surgical Technique/Implantation Model}

There are two different models representing different principles to test novel materials in bone: a wound model, where spontaneous healing will occur in a short time, provides information about osteocompatibility and inflammatory potential of a given material; and a model of large osseous defects [163], that do not heal spontaneously.

The correct placement of an implant is of utmost importance, as post implantation mobility leads to chronic inflammation with the development of a thick fibrous capsule with all its disadvantages [11-13].

\section{Mechanical Loading}

Bone is subjected to high strain $[164,165]$. In its function of load bearing continuous microdamage to bone occurs [166] that constantly demands structure remodelling. As described earlier this remodelling is mostly coordinated by bone forming cells (osteoblast, osteocytes and periostal cells), monocyte-derived osteoclasts and multinuclear cells. Extensive micromotion between implant and host bone leads to an intermediate layer between them. One has to keep in mind that this intermediate layer, also called interface membrane, cannot be distinguished according to its primary cause such as biocompatibility and/or mechanical problems. Tissue composition and cellular components are more less identical in both cases and again, this thick and fibrous layer severely disturbs osseointegration of any implant.

\section{Hormones}

Biomaterials inserted into bone normally elicit local and very seldom systemic responses. Therefore, the influence of systemic hormones may be negligible in most cases. Never- 
theless, hormones do influence the overall reaction of the immune system of a patient or an experimental animal which consequently may even have a - albeit relatively minor-local effect on immune response. Hormon concentrations may be directly related to the intensity of the immune response and as a result also to the tissue-implant response [148, 167]. High doses of steroid hormones could have significant down regulating effects on immune response [168]. High testosteron levels and low estrogen levels seem to depress immune function [169]. Estrogens are enhancers of humoral immunity [105].

\section{DISCUSSION AND CONCLUSIONS}

Different cell types interact and lead to specific responses. Understanding these mechanisms may allow us altering or influencing these interactions [170] and finally arrive at implant surfaces that promote greater biocompatibility. Every unnatural implant induces a natural foreign body response, thus, it is not the response by itself but its extent and intensity on which the biocompatibility of a medical device is determined. Therefore, any definition of biocompatibility related to a certain material should be based on quantitative evaluation of the cell population surrounding the implant, not just on the types of cells that occur.

The presence of macrophages and FBGCs including the development of some granulation tissue is a normal answer. For degradable materials the action of those cells are needed, as the result of an implantation otherwise would be a thick fibrous capsule around the device with all its negative consequences.

For permanent materials macrophages and FBGCs are responsible for the removal of wear debris that even in the best of cases cannot be prevented completely. However, a material, that remains relatively stable and unchanged in the surrounding tissue and a low amount of wear particles will not induce a permanent foreign body reaction leading to implant failure [11-13]. The body tissue seems to be capable of handling a continuous but minimal amount of wear debris without negative consequences, at least in bone. The appropriate and physiologic answer to the implantation seems to be the acute inflammatory reaction of the body with the mechanisms of macrophage and foreign body giant cell action for both permanent and degradable materials which ends up in either the bodies acceptance of the non-degradable device or the removal of the degradable foreign body as fast as it can be replaced by new bone. Only persistent inflammatory stimuli lead to chronic inflammation [69] including mononuclear cells like lymphocytes and plasma cells. Those are induced by the chemical and physical properties of the object or motion and if present in high numbers at the implant site lead to implant failure and/or rejection. In fact, the natural reaction of the body to foreign (bio) materials is similar to granuloma formation seen with infectious diseases (e.g. tuberculosis, parasites, such as trichinella, etc.,). There, granulomas are graded according to their biological activity [171]. Granulomas with low activity just there in the tissue for years without causing harm [172, 173].

However, since biomaterials are not infectious, but are either inert or fast or slowly degrading, resp. resorbing, it may be the extend of "granuloma" formation that determines their ultimate biocompatibility. A thin fibrous capsule may not be avoided and seemingly can be easily tolerated also in the bone. The same ist true for the presence of macrophages and/or FBGC. The material type, the speed of degradation and/or resorption may be responsible whether mainly macrophages alone will transport the material or whether fusion to FBGC resp. osteoclasts occurs [27, 55, 95-97, 117, 138]. Even low numbers of lymphocytes and plasmacytes occasionally present within the fibrous tissue surrounding the implant may not seriously jeopardize material acceptance, whereas the combination of a thick fibrous capsule, high numbers of macrophages, osteoclasts and/or FBGC and the presence of lymphocytes and plasmacytes can be considered a tissue reaction associated with bioincompatibility.

Even though a low tissue reaction to biomaterials may be tolerable, improvement of biomaterial surfaces should still be attempted. Future work should be directed towards $i$ ) the inhibition of the (immune) cell adhesion to (non-degradable) implants by adding antibodies that bind to the integrin receptor that recognizes the adhesion protein ii) the investigation of surface-chemistry for implanted (degradble or nondegradable) biomaterials, that modulate short- and long-term adhesion of monocytes and macrophages and FBGC fusion to the special needs of each type of implant, iii) the option to manipulate macrophage behaviour by harnessing some of the beneficial functions, like the expression of angiogenic and other growth [53].

Tissue responses may be further ameliorated and be kept to a minimum. Nevertheless, macrophages and FBGC may never be eliminated and may always be part of tissue response towards degradable materials.

\section{ACKNOWLEDGEMENTS}

The studies included in this publication were financed partly (grant for K.N.) by the National Centre of Competence (NCCR) CO-ME, Zurich, Switzerland granted by the Swiss National Funds (SNF).

\section{REFERENCES}

[1] Damien C, Parsons J. Bone graft and bone graft substitutes: A review of current technology and applications. J Appl Biomat 1991; 2: 187-208.

[2] Eid K, Zelicof S, Perona BP, Sledge CB, Glowacki J. Tissue reactions to particles of bone-substitute materials in intraosseous and heterotopic sites in rats: discrimination of osteoinduction, osteocompatibility, and inflammation. J Orthop Res 2001; 19(5): 962-9.

[3] Phemister DB. The fate of transplanted bone and regenerative power of its various constituents. Surg Gynecol Obstet 1914; 19(3): 303-33.

[4] Rechenberg Bv, Hofmann-Amtenbrink M, Meinel L. Introduction in biotechnology. In: Rüedi T, ed. AO philosophy and basic principles: AO/ASIF; 2006.

[5] Rechenberg Bv, Auer J. Bone grafts and bone replacements. In: Auer J, Stick J, eds. Equine surgery: Saunders Elsevier; 2006.

[6] Cooper SL, Visser SA, Hergenrother RW, Lamba NMK. Classes of materials used in Medicine: Polymers. In: Ratner B, Hoffmann AS, Schoen FJ, Lemons JE, eds. Biomaterials Science 2nd Ed. Oxford: Elsevier; 2004.

[7] Brodano GB, Cappuccio M, Gasbarrini A, et al. Vertebroplasty in the treatment of vertebral metastases: clinical cases and review of the literature. Eur Rev Med Pharmacol Sci 2007;11(2): 91-100.

[8] Manson NA, Phillips FM. Minimally invasive techniques for the treatment of osteoporotic vertebral fractures. Instr Course Lect 2007; 56: 273-85.

[9] Yablon I. The effect of methylmethacrylate on fracture healing. Clin Orthop 1976; (114): 358-63. 
[10] Revell P, Braden M, Freeman M. Review of the biological response to a novel bone cement containing poly(ethyl methacrylate) and n-butyl methacrylate. Biomaterials 1998; 19: 1579-86.

[11] El-Warrak A, Olmstead M, Apelt D. An animal model for interface tissue formation in cemented hip replacements. Vet Surg 2004; 33(5): 495-504.

[12] El-Warrak A, Olmstead M, Rechenberg Bv. A review of aspects of looseneng in total hip prosthesis. Vet Comparative Ortho Traumatol 2001; 3: 115 .

[13] El-Warrak A, Olmstead M, Schneider R. An experimental animal model of aseptic loosening of hip prostheses in sheep to study early biochemical changes at the interface membrane. BMC Musculoskelet Disord 2004; $5: 7$.

[14] Jagger D, Harrison A, Jandt K. The reinforcement of dentures. J Oral Rehabil 1999; 26: 185-94.

[15] Varghese S, Hwang NS, Canver AC, Theprungsirikul P, Lin DW, Elisseeff J. Chondroitin sulfate based niches for chondrogenic differentiation of mesenchymal stem cells. Matrix Biol 2008; 27(1): 12-21.

[16] Hokugo A, Sawada Y, Hokugo R, et al. Controlled release of platelet growth factors enhances bone regeneration at rabbit calvaria. Oral Surg Oral Med Oral Pathol Oral Radiol Endod 2007; 104(1): 44-8.

[17] Yamamoto M, Tabata Y, Hong L, Miyamoto S, Hashimoto N, Ikada Y. Bone regeneration by transforming growth factor betal released from a biodegradable hydrogel. J Control Release 2000; 64(1-3): 133-42.

[18] Yamamoto M, Takahashi Y, Tabata Y. Enhanced bone regeneration at a segmental bone defect by controlled release of bone morphogenetic protein-2 from a biodegradable hydrogel. Tissue Eng 2006; 12(5): 1305-11.

[19] Tabata Y, Yamada K, Hong L, Miyamoto S, Hashimoto N, Ikada Y. Skull bone regeneration in primates in response to basic fibroblast growth factor. J Neurosurg 1999; 91(5): 851-6.

[20] Takahashi Y, Yamamoto M, Yamada K, Kawakami O, Tabata Y. Skull bone regeneration in nonhuman primates by controlled release of bone morphogenetic protein-2 from a biodegradable hydrogel. Tissue Eng 2007; 13(2): 293-300.

[21] Kawaguchi H, Jingushi S, Izumi T, et al. Local application of recombinant human fibroblast growth factor-2 on bone repair: a dose-escalation prospective trial on patients with osteotomy. J Orthop Res 2007; 25(4): 480-7.

[22] Yamamoto M, Takahashi Y, Tabata Y. Controlled release by biodegradable hydrogels enhances the ectopic bone formation of bone morphogenetic protein. Biomaterials 2003; 24(24): 4375-83.

[23] Srouji S, Livne E. Bone marrow stem cells and biological scaffold for bone repair in aging and disease. Mech Ageing Dev 2005; 126(2): 281-7.

[24] Hench L, Best S. Ceramics, Glasses and Glass-Ceramics. In: Ratner B, Hoffman A, Schoen FJ, Lemons JE, eds. Biomaterials Science. 2nd Ed. San Diego: Elsevier; 2004.

[25] Chow L. Calcium phosphate materials: reactor response. Adv Dent Res 1988; 2: 181-4.

[26] Jarcho M. Biomaterials aspects of calcium phosphates: properties and applications. Dent Clin North Am 1986; 30: 25-47.

[27] Theiss F, Apelt D, Brand B, et al. Biocompatibility and resorption of a brushite calcium phosphate cement. Biomaterials 2005; 26: 4383-94.

[28] Yuan H, Li Y, de Bruijn JD, de Groot K, Zhang X. Tissue responses of calcium phosphate cement: a study in dogs. Biomaterials 2000; 21(12): 1283-90.

[29] Ignatius AA, Augat P, Ohnmacht M, Ponkinskyj P, Kock H, Claes L. A new bioresorbable polymer for screw augmentation in the osteosynthesis of osteoporotic cancellous bone: A biomechanical evaluation. J Biomed Mater Res 2001; 58: 254-60.

[30] Bohner M, Van Landuyt P, Merkle H, Lemaitre J. Composition effects on the $\mathrm{pH}$ of a hydraulic calcium phosphate cement. J Mater Sci Mater Med 1997; 8: 352-79.

[31] Frayssinet P, Gineste L, Conte P, Fages J, Rouquet N. Short-term implantation effects of a DCPD-based calcium phosphate cement. Biomaterials 1998; 19(11-12): 971-7.

[32] Levin M, Getter L, Adrain J, Cutright D. Healing of periodontal defects with ceramic implants. J Clin Periodontol 1974; 1: 197-205.

[33] Jarcho M. Calcium phosphate ceramics as hard tissue prosthetics. Clin Orthop 1981; 157: 259- 78.
[34] Steinbrunner RL, Brown CE, Jr., Legan JJ, Kafrawy AH. Biocompatibility of two apatite cements. J Endod 1998; 24(5): 335-42.

[35] Nancollas H. In vitro studies of calcium phosphate cristallisation. In: Mann S, Webb J, Williams R, eds. Biomineralization Chemical and biochemical perspectives. New York: VCH; 1989. p. 157-82.

[36] Thomas K, Kay J, Cook S, Jarcho M. The effect of surface macrotexture and hydroxyapatite coating on the mechanical strengths and histologic profiles of titanium implant materials. J Biomed Mater Res 1987; 21: 1395-414.

[37] Byrd H, Hobar P, Shewmake K. Augmentation of the craniofacial skeleton with porous hydroxyapatite granules. Plast Reconstr Surg 1993; 91: 15-22.

[38] Satoh K, Nakatsuka K. Simplified procedure for aesthetic improvement of facial contour by maxillary augmentation using a porous hydroxyapatite graft for maxillofacial deformity. Plast Reconstr Surg 1996; 97: 338-44.

[39] Ylinen P, Suuronen R, Taurio R, Tormala P, Rokkanen P. Use of hydroxylapatite/ polymer-composite in facial bone augmentation. An experimental study. Int J Oral Maxillofac Surg 2002; 31(4): 405-9.

[40] Geesink R. Osteoconductive coatings for total joint arthroplasty. Clin Orthop 2002; 395: 53-65.

[41] Bohner M. Calcium orthophosphates in medicine: from ceramics to calcium phosphate cements. Injury 2000; 31(Suppl 4): 37-47.

[42] Bohner M, Van Landuyt P, Trophardy G, Merkle H, Lemaitre J. Effect of several additives and their admixtures on the physicochemical properties of a calcium phophate cement. J Mater Sci Mater Med 2000; 11(2): 111-6.

[43] Hong L, Hengchang X, de Groot K. Tensile strength of the interface between hydroxyapatite and bone. J Biomed Mater Res 1992; 26(1): 7-18.

[44] Bloebaum RD, Dupont JA. Osteolysis from a press-fit hydroxyapatite-coated implant. A case study. J Arthroplasty 1993 ; 8(2): 195202.

[45] Laquerriere P, Grandjean-Laquerriere A, Jallot E, Balossier G, Frayssinet P, Guenounou M. Importance of hydroxyapatite particles characteristics on cytokines production by human monocytes in vitro. Biomaterials 2003; 24(16): 2739-47.

[46] Yannas I. Classes of materials used in medicine: Natural materials. In: Ratner B, Hoffman A, Schoen F, Lemons J, eds. Biomaterials Science. 2nd Ed. San Diego: Elsevier; 2004.

[47] Rosengren A, Wallman L, Danielsen N, Laurell T, Bjursten LM. Tissue reactions evoked by porous and plane surfaces made out of silicon and titanium. IEEE Trans Biomed Eng 2002; 49(4): 392-9.

[48] Misiek D, Kent J, Carr R. Soft-tissue responses to hydroxyapatite particles of different shapes. J Oral Maxillofac Surg 1984; 42: 15060 .

[49] Sevastianov V. Role of protein adsorption in blood compatibility of polymers. Crit Rev Biocompat 1988; 44: 109-54.

[50] Gristina A, Dobbins J, Giammara B, Lewis J, DeVries W. Biomaterial-centered sepsis and the total artificial heart. JAMA 1988; 259: 870-4.

[51] Anderson J, Bonfield T, Ziats N. Protein adsorption and cellular adhesion and activating on biomedical polymers. Int J Artif Org 1990; 13: 375-82.

[52] Tang L, Lucas A, Eaton J. Inflammatory responses to Dacron: role of surface adsorbed IgG. J Lab Clin Med 1993; 122: 292-300.

[53] Horbett T. The role of adsorbed proteins in tissue response to biomaterials. In: Ratner B, Hoffman A, Schoen FJ, Lemons JE, eds. Biomaterials Science 2nd Ed. San Diego: Elsevier; 2004.

[54] Tang L, Jennings T, Eaton J. Mast cells mediate acute inflammatory responses to implanted biomaterials. Proc Natl Acad Sci USA 1998; 95: 8841-6.

[55] Santavirta S, Gristina A, Konttinen YT. Cemented versus cementless hip arthroplasty. A review of prosthetic biocompatibility. Acta Orthop Scand 1992; 63(2): 225-32.

[56] Anderson JM. Inflammatory response to implants. ASAIO Trans 1988; 34(2): 101-7.

[57] Santavirta S, Pajamäki J, Konttinen YT, Eskola A, Lindholm T. Proliferative cell response to the loosening of THR. A cytofluorographic cell cycle analysis. Arch Orthop Trauma Surg 1991; 111: 43-6.

[58] Ikarashi Y, Toyoda K, Ohsawa N. Comparative studies by cell culture and in vivo implantation test on the toxicity of natural rubber later materials. J Biomed Mater Res 1992; 26: 339-56. 
[59] Moore JW, Brekke JH. Foreign body giant cell reaction related to placement of tetracyclin-treated polylactid acid: Report of 18 cases. J Oral Maxillofac Surg 1990; 48(8): 808-12.

[60] Maguire JK, Coscia MF, Lynch MH. Foreign body reaction to polymeric debris following total hip arthroplasty. Clin Orthop Relat Res 1987; (216): 213-23.

[61] Bergsma EJ, Rozema FR, Bos RR, de Bruijn WC. Foreign body reactions to resorbable poly(L-lactide) bone plates and screws used for the fixation of unstable zygomatic fractures. J Oral Maxillofac Surg 1993; 51(6): 666-70.

[62] Apelt D, Theiss F, El-Warrak A, et al. In vivo behaviour of three different injectable hydraulic calcium phosphate cements. Biomaterials 2004; 25 : 1439-51.

[63] Galante JO, Lemons J, Spector M, Wilson PD Jr, Wright TM. The biologic effects of implant materials. J Orthop Res 1991; 9: 760-75.

[64] St. John KR. Particulate debris from medical implants: mechanisms and formation and biological consequences. Philadelphia: American Society for Testing and Materials; 1992.

[65] Boss JH, Shajrawi I, Aunullah J, Mendes DG. The relativity of biocompatibility. A critique of the concept of biocompatibility. Isr J Med Sci 1995; 31(4): 203-9.

[66] Campbell CE, von Recum AF. Microtopography and soft tissue response. J Invest Surg 1989; 2: 51-74.

[67] Williams DF. The development and control of the host response to implanted polymers. International Conference on Biomedical Polymers: From Molecular Design to clinical Applications; 1991; Jerusalem. UNESCO.

[68] Anderson J. Inflammation and the foreign body response. Problems Gen Surg 1994; 11: 147-60.

[69] Anderson J. Inflammation, wound healing and the foreign body response. In: Ratner B, Hoffmann A, Schoen FJ, Lemons JE, eds. Biomaterials Science 2nd Ed. San Diego: Elsevier; 2004.

[70] Marks S, Popoff S. Bone cell biology. Am J Anat 1988; 183: 1-44.

[71] Gartner L, Hiatt J. Color textbook of histology. 2nd Ed. Philadelphia: W.B Saunders Company; 2001.

[72] Fallon M, Teitelbaum S. A simple procedure for the rapid histologic diagnosis of metabolic bone disease. Calcif Tissue Int 1981; 33: 281-3.

[73] Kadoya K, Al-Saffar N, Kobayashi A, Revell P. The expresson of osteoclast-markers on foreign body giant cells. Bone Miner 1994; 27: 85-96.

[74] Willert H, Bertram H, Buchhorn G. Osteolysis in alloarthroplasty of the hip: the role of bone cement fragmentation Clin Orthop 1990; 258: 108-21.

[75] Wang W, Ferguson DJ, Quinn JM, Simpson AH, Athanasou NA. Biomaterial particle phagocytosis by bone-resorbing osteoclasts. J Bone Joint Surg Br 1997; 79(5): 849-56.

[76] Athanasou NA. Colour atlas of bone, joint and soft tissue pathology. New York: Oxford University Press, New York; 1999.

[77] Brodbeck WG, Macewan M, Colton E, Meyerson H, Anderson JM. Lymphocytes and the foreign body response: lymphocyte enhancement of macrophage adhesion and fusion. J Biomed Mater Res 2005; 74(2): 222-9.

[78] Coleman D, King R, Andrade J. The foreign body reaction: a chronic inflammatory response. J Biomed Mater Res 1974; 8: 199211.

[79] Zeller JM. Surgical implants. Physiological response. Aorn J 1983; 37(7): 1284-91.

[80] Ziats NP, Miller KM, Anderson JM. In vitro and in vivo interactions of cells with biomaterials. Biomaterials 1988; 9(1): 5-13.

[81] Morehead JM, Holt GR. Soft-tissue response to synthetic biomaterials. Otolaryngol Clin North Am 1994; 27(1): 195-201.

[82] Wewers M. Cytokines in health and disease. New York: Marcel Dekker; 1992.

[83] Tang L, Chesney J, Sherry B, Eaton J. The pivotal roles of cytokines in the recruitment and adhesion of inflammatory cells to implanted biomaterials. Trans Soc Biomater 1997; 23: 127.

[84] Remes A, Williams D. Chemotaxis and the inhibition of chemotaxis of human neutrophils in response to metal ions. J Mat Sci Mat Med 1990; 1: 26-32.

[85] Tang L, Eaton J. Fibrin (ogen) mediates acute inflammatory responses to biomaterials. J Exp Med 1993; 178: 2147-56.

[86] Shen M, Garcia I, Maier RV, Horbett TA. Effects of adsorbed proteins and surface chemistry on foreign body giant cell formation, tumor necrosis factor alpha release and procoagulant activity of monocytes. J Biomed Mater Res A 2004; 70(4): 533-41.
[87] Jenney C, Anderson J. Adsorbed IgG:a potent adhesive substrate for human macrophages. J Biomed Mater Res 2000; 50: 281-90.

[88] Audran R, Lesimple T, Delamaire M, Picot C, Van Damme J, Toujas L. Adhesion molecule expression and response to chemotactic agents of human monocyte-derived macrophages. Clin Exp Immunol 1996; 103: 155-60.

[89] Nathan C. Secretory products of macrophages. J Clin Invest 1987; 79: 319-26

[90] Riches D, Chan E, Winston B. TNF-alpha induced regulation and signaling inmacrophages. Immunobiology 1996; 195: 477-90.

[91] Montesaro R, Orci L, Vassalli P. Human endothelial cell cultures: phenotypic modulation by leukocyte interleukins. J Cell Physiol 1985; 122(3): 424-34.

[92] Schmidt J, Mizel S, Cohen D, Green I. Interleukin-1, a potential regulator of fibroblast proliferation. J Immunol 1982; 128: 673-8.

[93] Goodman SB. Does the immune system play a role in loosening and osteolysis of total joint replacements? J Long Term Eff Med Implants 1996; 6(2): 91-101.

[94] Hagerty RD, Salzmann DL, Kleinert LB, Williams SK. Cellular proliferation and macrophage population associated with implanted expanded polytetrafluoroethylene and polyethylene terephthalate. J Biomed Mater Res 2000; 49: 489-97.

[95] Konttinen YT, Zhao D, Beklen A, et al. The microenvironment around total hip replacement prostheses. Clin Orthop Relat Res 2005; (430): 28-38.

[96] Lassus J, Konttinen Y, Li T. Aseptic loosening of total hip prosthesis. In: Lindholm T. ed. Skeletal reconstruction and bioimplantation. Austin, Texas, USA: Landes Bioscience; 1997.

[97] Lassus J, Salo J, Jiranek W, et al. Macrophages activation results in bone resorption. Clin Orthop Relat Res 1998; 352: 7-15.

[98] Haynes D, Roger S, Hay S, Pearcy M, Howie D. The differences in toxicity and release of bone-resorbing mediators induced by titanium and cobalt-chromium-alloy wear particles J Bone Jt Surg 1993; 75A: 825-34.

[99] Anderson J, Miller K. Biomaterial biocompatibility and the macrophage. Biomaterials 1984; 5: 5-10.

[100] Sabokbar A, Kudo O, Athanasou NA. Two distinct cellular mechanisms of osteoclast formation and bone resorption in periprosthetic osteolysis. J Orthop Res 2003; 21: 73-80.

[101] Sabokbar A, Fujikawa Y, Murray DW, Athanasou NA. Radioopaque agents in bone cement increase bone resorption. J Bone Joint Surg Br 1997; 79(1): 129-34.

[102] Kao W, Mc Nally AK, Hiltner A, Anderson J. Role for interleukin4 in foreign body giant cell formation on a polyetherurethane urea in vivo. J Biomed Mater Res 1995; 29: 1267-75.

[103] McNally AK, Anderson JM. Interleukin-4 induces foreign body giant cells from human monocytes/makrophages. Am J Pathol 1995; 147: 1487-99.

[104] McInnis A, ERennick D. Interleukin-4 induces cultured monocytes/macrophages to form multinucleated cells. J Exp Med 1988; 167: 598-611.

[105] Butler KR, Jr., Benghuzzi HA. Morphometric analysis of the hormonal effect on tissue-implant response associated with TCP bioceramic implants. Biomed Sci Instrum 2003; 39: 535-40.

[106] Leibovich S, Ross R. The role of the macrophage in wound repair. Am J Pathol 1975; 78: 71-91.

[107] Muller-Mai C, Voigt C, Hering A, Rahmanzadeh R, Gross U. [Madreporic hydroxyapatite granulates for filling bone defects]. Unfallchirurg 2001; 104(3): 221-9.

[108] Vogel M, Voigt C, Knabe C, Radlanski RJ, Gross UM, Muller-Mai $\mathrm{CM}$. Development of multinuclear giant cells during the degradation of Bioglass particles in rabbits. J Biomed Mater Res A 2004; 70(3): 370-9.

[109] Murch A, Grounds M, Marshall C, Papadimitriou J. Direct evidence that inflammatory multinucleate cells form by fusion. $\mathrm{J}$ Pathol 1982; 137: 177-80.

[110] DeFife KM, Jenney CR, Colton E, Anderson JM. Disruption of filamentous actin inhibits human macrophage fusion. FASEB J 1999; 13(8): 823-32.

[111] Kazazi F, Chang J, Lopez A, Vadas M, Cunningham A. Interleukin-4 and human immunodeficiency virus stimulate LFA-1-ICAM1-mediated aggregation of monocytes and subsequent giant cell formation. J Gen Virol 1994; 75: 2795-802.

[112] Smetana K, Jr. Multinucleate foreign-body giant cell formation. Exp Mol Pathol 1987; 46: 258-65 
[113] Zhao Q, Topham N, Anderson JM, Hiltner A, Lodoen G, Payet CR. Foreign-body giant cells and polyurethane biostability: in vivo correlation of cell adhesion and surface cracking. J Biomed Mater Res 1991; 25(2): 177-83.

[114] Sorimachi K, Akimoto K, Tsuru K, Ieiri T, Niwa A. The involvement of tumor necrosis factor in the multinukleation of macrophages. Cell Biol Int 1995; 19: 547-9.

[115] Mittermayer C, Eblenkamp M, Richter HA, Zwadlo-Klarwasser G, Bhardwaj RS, Klosterhalfen B. Pathology of implants. Kongressbd Dtsch Ges Chir Kongr 2002; 119: 491-7.

[116] Mohanty M. Cellular basis for failure of joint prosthesis. Biomed Mater Eng 1996; 6(3): 165-72.

[117] Konttinen Y, Xu J, Patiala H. Cytokines in aseptic loosening of total hip replacement. Curr Orthop 1997; 11: 40-7.

[118] Zhao Q, Agger M, Fitzpatrick M, et al. Cellular interactions with biomaterials: In vivo cracking of pre-stressed Pellethane 2363-80A. J Biomed Mat Res 1990; 24: 621-37.

[119] Schlesinger L, Musson R, Johnston R. Functional and biochemical studies of multinucleated giant cells derived from the culture of human monocytes. J Exp Med 1984; 159: 1289-94.

[120] Quinn J, Joiner C, Triffitt J, Athanasou N. Polymethylmethacrylate-induced inflammatory macriphages resorb bone. J Bone Joint Surg (Br) 1992; 74: 652-8.

[121] Pandey R, Quinn JM, Sabokbar A, Athanasou NA. Bisphosphonate inhibition of bone resorption induced by particulate biomaterialassociated macrophages. Acta Orthop Scand 1996; 67(3): 221-8.

[122] Sabokbar A, Pandey R, Quinn JM, Athanasou NA. Osteoclastic differentiation by mononuclear phagocytes containing biomaterial particles. Arch Orthop Trauma Surg 1998; 117(3): 136-40.

[123] Kawaguchi H, Ogawa T, Shirakawa H, Okamoto H, Akisaka T. Ultrastructural and ultrscytochemical characteristics of multinucleated cells after hydroxyapatite implantation into rat periodontal tissue. J Periodontal Res 1992; 27: 48-54.

[124] Chambers T, Spector W. Inflammatory giant cells. Immunobiology 1982; 161: 283-9.

[125] Dersot JM, Colombier ML, Lafont J, Baroukh B, Septier D, Saffar JL. Multinucleated giant cells elicited around hydroxyapatite particles implanted in craniotomy defects are not osteoclasts. Anat Rec 1995; 242(2): 166-76.

[126] Chu C. Biodegradable polymeric biomaterials: an overview. In: Bronzino J. The biomedical engeneering handbook. Boca Ranton, FL: CRC Press; 1995. p. 611-26.

[127] Hochuli-Vieira E, Cabrini Gabrielli MA, Pereira-Filho VA, Gabrielli MF, Padilha JG. Rigid internal fixation with titanium versus bioresorbable miniplates in the repair of mandibular fractures in rabbits. Int J Oral Maxillofac Surg 2005; 34(2): 167-73.

[128] Holmbom J, Sodergard A, Ekholm E, et al. Long-term evaluation of porous poly(epsilon-caprolactone-co-L-lactide) as a bone-filling material. J Biomed Mater Res A 2005; 75(2): 308-15.

[129] Klein CP, Van der Lubbe H, Driessen AA, de Groot K, Van den Hoof A. Biodegradation behaviour of various calciumphosphate materials in subcutaneous tissue. In: Vincencini P, ed. Ceramics in surgery. Amsterdam: Elsevier; 1983. p. 105-15.

[130] Dersot JM, Septier D, Llorens A, Saffar JL. Multinukleated giant cells-a time-related quantitative study in a rat skull defect. Cells Mater 1993; 3: 395-405.

[131] Klein CP, de Groot K, Driessen AA, Van der Lubbe H. A comparative study of different beta-whitlockite ceramics in rabbit cortical bone with regard to their biodegradation behaviour. Biomaterials 1986; 7: 144-6.

[132] Dupraz A, Delecrin J, Moreau A, Pilet P, Passuti N. Long-term bone response to particulate injectable ceramic. J Biomed Mater Res 1998; 42(3): 368-75.

[133] Cutright DE, Hunsuck EE. Tissue reaction to the biodegradable polylactic acid suture. Oral Surg Oral Med Oral Pathol 1971;31(1): 134-9.

[134] Papadimitriou J, Sforsina D, Papaelias L. Kinetics of multinucleate giant cell formation and their modification by various agents in foreign body reaction. Am J Pathol 1973; 73: 349-64.

[135] Jenney CR, Anderson JM. Effects of surface-coupled polyethylene oxide on human macrophage adhesion and foreign body giant cell formation in vitro. J Biomed Mater Res 1999; 44(2): 206-16.

[136] Stokes K, McVenes R, Anderson J. Polyurethane Elastomer Biostability. J Biomater Appl 1995; 9: 321-54.

[137] Brodbeck WG, Shive MS, Colton E, Nakayama Y, Matsuda T, Anderson JM. Influence of biomaterial surface chemistry on the apoptosis of adherent cells. J Biomed Mater Res 2001; 55(4): 6618.

[138] Santavirta S, Hoikka V, Eskola A. Aggressive granulomatous lesion in cementless total hip arthroplasty. J Bone Joint Surg 1990; 72: $980-4$.

[139] Goreish HH, Lewis AL, Rose S, Lloyd AW. The effect of phosphorylcholine-coated materials on the inflammatory response and fibrous capsule formation: in vitro and in vivo observations. J Biomed Mater Res A 2004; 68(1): 1-9.

[140] Thomsen P, Ericson L. Inflammatory cell response to bon implant surfaces. In: Davies J. The Bone-Biomaterial Interface. Toronto, Canada: University Toronto Press; 1991.

[141] Branemark P, Lausmaa J, Ericson L, Thomsen P, Branemark R, Skalak R. Anatomy of osseointegration and the tranfer of load. In: Foneseca R, Davis W. Reconstructive preprosthetic oral and maxillofacial surgery. Philadelphia, PA: Saunders; 1995. pp. 165-224.

[142] Hench L, Wilson J. Surface-active biomaterials. Science 1984; 226 : 630-6.

[143] Cadee JA, Van Luyn MJ, Brouwer LA, et al. In vivo biocompatibility of dextran-based hydrogels. J Biomed Mater Res 2000; 50(3): 397-404.

[144] Jeyanthi R, Rao KP. In vivo biocompatibility of collagenpoly(hydroxyethyl methacrylate) hydrogels. Biomaterials 1990; 11(4): 238-43.

[145] Eriksson C, Nygren H, Ohlson K. Implantation of hydrophilic and hydrophobic titanium discs in rat tibia: cellular reactions on the surfaces during the first 3 weeks in bone. Biomaterials 2004; 25(19): 4759-66.

[146] Ungersbock A, Pohler O, Perren SM. Evaluation of the soft tissue interface at titanium implants with different surface treatments: experimental study on rabbits. Biomed Mater Eng 1994; 4(4): 317-25.

[147] Costantino P, CD F, Lane A. Synthetic biomaterials in facial plastic and reconstructive surgery. Facial Plast Surg 1993; 9: 1-15.

[148] Butler KR Jr., Benghuzzi HA. Immunohistochemical detection of cytokine expression in tissue-implant response associated with TCP bioceramic implants loaded with steroid hormones. Biomed Sci Instrum 2003; 39: 541-6.

[149] Bocchiotti G, Verna G, Fracalvieri M, Fanton E, Datta G, Robotti E. Carbofilm-covered prostheses in plastic surgery: preliminary observations. Plast Reconstr Surg 1993; 91(1): 80-8; discussion 9-90.

[150] Van Blitterswijk CA, Bakker D, Hesseling SC, Koerten HK. Reactions of cells at implant surfaces. Biomaterials 1991; 12(2): 187-93.

[151] Von Recum A, Van Kooten T. The influence of microtopography on cellular response and the implications for silicone implants. J Biomater Sci Polym Edn 1995; 7: 181-98.

[152] Holmes R. Bone regeneration within a coralline hydroxyapatite implant. Plast Reconstr Surg 1979; 63: 626-33.

[153] Hutmacher D. Scaffolds in tissue engineering bone and cartilage. Biomaterials 2000; 21: 2529-43.

[154] Ekholm E, Hietaniemi K, Määttä A, Vouorio E, Paavolainen P, Penttinen R. Extended expression of cartilage components in experimental pseudarthrosis. Connect Tissue Res 1995; 31: 211-8.

[155] Bos RR, Rozema FR, Boering G, et al. Degradation of and tissue reaction to biodegradable poly(L-lactide) for use as internal fixation of fractures: a study in rats. Biomaterials 1991; 12(1): 32-6.

[156] Sevastjanova N, Mansurova L, Dombrovska L, Slutkii L. Biochemical characterization of connective tissue reaction to synthetic polymer implants. Biomaterials 1987; 8: 242-7.

[157] Koerten H, Van Blitterswijk CA, Hesseling SC, Grote JJ. Trace element accumulation after macrophage/material interactions. In: Heimke G, Soltesz U, Lee A, eds. Clinical implant materials. Amsterdam: Elsevier; 1990. p. 219.

[158] Bakker D, Van Blitterswijk CA, Hesseling SC, Grote JJ. Effect of implantation site on phagocyte/polymer interaction and fibrous capsule formation. Biomaterials 1988; 9(1): 14-23.

[159] Bakker D, Van Blitterswijk CA, Hesseling SC, Grote JJ. Biodegradation and phagocyte/polymer interaction. In: Williams K, Lasser T. Interfaces in medicine and mechanics. Trowbridge: Dotesios; 1989. p. 110

[160] Van Blitterswijk CA, Koerten HK, Bakker D, Hesseling SC, Grote JJ. Biodegradation dependent trace element accumulation: a study on calcium phosphate ceramics and polymers. In: Williams $\mathrm{K}$, Lesser T, eds. Interfaces in medicine and mechanics. Trowbridge: Dotesios; 1989. p. 110. 
[161] Boss JH, Shajravi I, Soudry M. Histological features of the interface membrane of failed isoelastic cementless prostheses. Int Orthop 1990; 14: 399-403.

[162] Williams DF. Introduction. In: Williams DF, editor. Biocompatibility of orthopedic implants. Boca Raton, FL: CRC Press; 1985.

[163] Anderson M, Dhert W, de Bruijn J, et al. Critical size defect in the goat's os ilium. A model to evaluate bone grafts and substitutes. Clin Orthop 1999; 364: 231-9.

[164] Wolff J. Das Gesetz der Transformation der Knochen. Berlin: A. Hirschwald; 1882.

[165] Wolff J. Über die Wechselbeziehungen zwischen der Form und der Funktion der einzelnen Gebilde des Organismus. 1st Ed. Leipzig: FCW Vogel; 1901.

[166] Kawcak CE, McIlwraith CW, Norrdin RW, Park RD, James SP. The role of subchondral bone in joint disease: a review. Equine Vet J 2001; 33(2): 120-6.

[167] Hughes T, Rady P, Smith E. Potential for the effects of anabolic steroid abuse in the immune and neuroendocrine axis. J Neuroimmunol 1998; 83 (1-2): 162-7.
[168] Hughes T, Fulep E, Juelich T, Smith E, Stanton G. Modulation of immune responses by anabolic androgenic steroids. Int J Immunopharmacol 1995; 17(11): 857-63.

[169] Angele M, Ayala A, Monfils B, Cioffi W, Bland K, Chaudry I. Testosterone and/or low estradiol: normally required but harmful immunologically for males after trauma haemorrhage. J Trauma 1998; 44(1): 78-85.

[170] Cima L. Polymer substrates for controlled biological interactions. J Cell Biochem 1994; 56: 155-61.

[171] Sarraf P, Sneller M. Pathogenesis of granuloma formation. Expert reviews in molecular medicine. [abstract]. 2005; 13.5.2005; 7(8).

[172] Lepenies J. Helminthen. In: Bühling K, Lepenies J, Witt K. Intensivkurs Pathologie, Allgemeine und spezielle Pathologie. 3rd Ed. München: Urban und Fischer; 2001.

[173] Joachim A. Trichinellose. In: Schnieder T. Veterinärmedizinische Parasitologie. 6th Ed. Stuttgart: Parey; 2006.

(C) Nuss and von Rechenberg; Licensee Bentham Open.

This is an open access article distributed under the terms of the Creative Commons Attribution License (http://creativecommons.org/license/by/2.5/), which permits unrestrictive use, distribution, and reproduction in any medium, provided the original work is properly cited. 